Papers and Proceedings of the Royal Society of Tasmania, Volume 113, 1979.

(ms. received 9.1 .1979$)$

\title{
A PERMIAN FAULT IN NORTH-WESTERN TASMANIA
}

by Maxwel1 R. Banks

University of Tasmania

(with one text figure and two plates)

\section{ARSTRACT}

BANKS, M.R., 1979 (20 vii): A Permian fault in north-western Tasmania. Pap. Proc. R. Soe. Tasm., 113: 185-191 (incl. two plates). ISSN 0080-4703. Department of Geology, University of Tasmania, Hobart, Tasmania, Australia.

Evidence is advanced to show that faulting occurred during deposition of the Mersey Coal Measures (Early Permian) near Sassafras in north-western Tasmania. INTRODUCTION

Intrastratal faults in Permian sequences in Tasmania have been known for a1most 53 years. David (1926, p.102) figured such faults from Firewood siding in western Tasmania in a Late Permian carbonaceous sequence and interpreted the faulting and accompanying brecciation as due to glacial over-riding during the Pleistocene, a view rejected by Banks and Ahmad (1959, p.125) in favour of a relationship with normal faulting. Such intrastratal deformation involving faulted competent horizons within carbonaceous sequences has been seen elsewhere in the Permian of Tasmania and figured from coal-measures of other ages and elsewhere (e.g. Stutzer and Noe 1940).

Recent widening of the Bass Highway $3.1 \mathrm{~km}$ south of Parramatta Creek and about $9.5 \mathrm{~km}$ along the road south-east of Sassafras at 8215 - 466215, has revealed a steep contact between two slightly different sequences of almost horizontal Permian beds with one of the sequences projecting over the contact (fig. 1). There is thus, prima facie evidence of an unconformity or a Permian fault. The beds concerned belong to the Mersey Coal Measures and have been recently shown to contain a microflora belonging to Microfloral Zone $3 \mathrm{~b}$ of the Permian (Truswell 1978, pp.15-16).

The photographs were taken by Mr. J. Hodgman, Photographic Section, University of Tasmania. I am indebted to Dr. E. Williams, Department of Mines, for helpful criticism.

\section{THE UPTHROWN BLOCK}

Strata of the upthrown block are exposed in the gutter and in cuttings on the western side of the road and north of the fault on the eastern side of the road (fig. 1). The sequence commences with a siltstone which weathers pink and is at least $1.4 \mathrm{~m}$ thick. This is followed by $0.1 \mathrm{~m}$ of coarse friable conglomerate overlain by about $2.25 \mathrm{~m}$ of cross-bedded, feldspathic sandstone and then by at least $2 \mathrm{~m}$ of carbonaceous siltstone with thin fine-grained sandstone beds. It is this uppermost unit which outcrops against the fault contact on the eastern side of the road. The sequence appears to form part of two fluvial cycles.

In the northern part of the cutting on the eastern side of the road, the carbonaceous siltstone dips north or north-westerly at about $5^{\circ}$ (pl. 1, fig. 1). The siltstone passes up along an irregular almost horizontal surface into a 1 eached, clayey zone (p1. 1, fig. 2). The leached zone is in turn overlain by a sequence of thinly-bedded carbonaceous siltstone and fine sandstone which dips at about $5^{\circ}$ to the south or south-east and the upper beds of which continue south over and beyond the steep contact. The leached zone probably represents a podsolic soil developed on an unconformity surface. 


A

FIG. 1.- (a) Map showing position of Sassafras; (b) Map showing position of road cutting; (c) Sketch of cutting derived from panoramic photographic view; showing fault, intrastratally folded beds and several other beds on both sides of the fault.

The sequence in the upthrown block is sedimentologically akin to the Mersey Coal Measures and bears no resemblance to the marine or estuarine sedimentary rocks of the underlying formation. It was mapped as part of an outcrop of Mersey Coal Measures by Gulline et al. (1973) and the evidence supports this assignment.

\section{THE DOWNTHROWN BLOCK}

The rocks on the downthrown or south-eastern block form part of two fluvial cycles. At the southern end of the cutting carbonaceous siltstone crops out probably representing deposition in a flood-plain lake. This is overlain by a thin ( $1 \mathrm{~m}$ ) bed of coarse-grained, cross-bedded quartz sandstone (p1. 1, fig. 3), a channe1 and point bar deposit, which is overlain by carbonaceous siltstone $1.5 \mathrm{~m}$ thick in places but dying out towards the southern end of the cutting. The siltstone, which may represent a pool in a swale or an ox-bow lake, is overlain by thinly interbedded beds of carbonaceous siltstone and fine-grained ripple-marked siliceous sandstone with fine scale cross-bedding representing flood plain and levée bank deposits. The interbedded sequence is about $5 \mathrm{~m}$ thick and from half way up this sequence or a little higher the specimens dated by Truswe11 (1978) were derived.

Close to the fault the sequence dips shallowly south-east but the dip reverses about $30 \mathrm{~m}$ south-east of the fault and becomes almost horizontal with perhaps a slight component to the north (fig. 1c).

Within the sequence south of the fault are two beds with intrastratal folding, the lower of which outcrops against the fault at gutter level and is carried by the dip below the ground surface $12 \mathrm{~m}$ from the contact. This lower bed re-emerges $58 \mathrm{~m}$ from the contact beyond which it continues, broken in outcrop by material slipping down from higher up the cut, to a point $178 \mathrm{~m}$ from the contact where the rocks in the cut become indistinct. The upper intrastratally folded bed crops out for only a few metres south of the contact.

The lower intrastratally folded bed is at the base of the sequence of interbedded carbonaceous siltstone and fine sandstone, i.e. at the base of the levé bank and flood plain sequence. It is about one metre thick but thins out completely in some places. It consists of a series of lobes, some disconnected, some overriding other lobes from the north (pl. 1, fig. 3; pl. 2, fig. 1). The lobes are consistently rounded to the south and thinned or pointed and disconnected to the north. The lobes have axial surfaces which are almost parallel to the bedding in many cases but some make an angle of up to $30^{\circ}$ with the bedding. The axial surfaces dip towards the fault in some places, 
Maxwe11 只. Banks

away from it in others. The trend of the one fold lobe exposed in the gutter is $128^{\circ}$ and this is also the trend of the axis measured on one excavated fold close to the fault. The fold hinge dips to $128^{\circ}$ at about $2^{\circ}$. No sign of erosion along the top surface of the intrastratally convoluted bed was detected but the contact was by no means clearly exposed. The folds have a geometry which best fits a slump origin and it is interesting to note that Conybeare and Crook (1968, pp.38-9) comment on the occurrence of slumps produced by lydroplastic flow resulting from collapse of alluvial sediments particularly of the upper parts of point bar deposits. In the bed most of the deformation seems to have been by folding and to most closely match "slurry slump bedding" (Conybeare and Crook 1968, p.39, Plate 38). Some of the beds slightly above the lower intrastratally folded bed show minor deformation by contemporaneous faulting (p1. 2, fig. 2).

The beds of the downthrown block are sedimentologically like those of the upthrown block (but with some differences in thicknesses and succession) and thus also like the Mersey Coal Measures. In fact thin (a few $\mathrm{mm}$ ) seams of vitrinite may be found not far above the lower intrastratally folded bed. In addition there is palynological evidence (Truswell 1978) that this sequence contains the same microflora as the Mersey Coal Measures.

\section{THE FAULT ZONE}

When viewed approximately along strike (p1. 1, fig. 1) the fault is seen to be a steep, slightly irregular contact. It is difficult to measure the strike accurately, but it is approximate $1 y 33^{\circ}$. The beds on the downthrown block dip slightly more steeply away from the fault near it than they do further away suggesting a drag dip on a normal fault. In the lower part of the cutting there is a fault zone several tens of centimetres wide occupied by dipping beds of carbonaceous siltstone like that on the upthrown side, the dip near the gutter being slightly steeper than, but in the same direction as, the dip of the beds in the downthrown block (p1. 2, fig. 3). Higher in the fault horse, the beds of siltstone are horizontal or dip gently north. The fault does not break the higher beds in the sequence which continue over it with a slight change of dip from downthrown to upthrown block. No precise information is available on the throw of the fault but it is more than $1.5 \mathrm{~m}$ but less than the stratigraphic thickness of the Mersey Coal Measures (approximately $35 \mathrm{~m}$ ).

The contact has been interpreted as a fault because of the discontinuity, the change in dip on opposi.te sides of the contact, the presence of a fault horse with beds of a third dip and the angular unconformity on the upthrown block. One or more of these criteria could be equally explained by postulating that the contact was an unconformity, a steep, croded channel bank or the failure surface of a landslide such as might occur in a steep, ox-bow bank but none of these possibilities satisfies all criteria as does the fault solution. It is therefore concluded that the contact is a fault.

Mild tectonic activity has been postulated to have affected Tasmania during the Permian Period on the basis of change in isopach patterns (Banks 1962, p.215) and may well have beeri the cause of sharp changes in sediment type (Cascades Group to Malbina Formation in the ivit. Nassau area, Banks and Read 1962, p.23) associated with absence of a faunal assemblage zone (Clarke and Banks 1975, fig. 33.4, p.460) and of other paraconformities (contact betheen Faunal Zones 2 and 5 in the Cygnet area - Clarke and Banks 1975, pp.460-1), but no evidence in the form of intra-Permian angular unconformities has been advanced. It is possible that the fault described here, as well as the evidence of angular unconformity and exposure to weathering on the upthrown block, may provide such evidence. However, before this exposure can be taken as evidence of a stress operating at the time in the crust beneath Tasmania and thus be thought of as tectonic in a proper sense, a superficial origin would have to be 
eliminated. This cannot be done on the evidence available and a superficial origin is even rather likely.

A superficial origin is suggested by similar occurrences in coal measures elsewhere as noted earlier and the common occurrence of growth faults in deltaic successions elsewhere (see Edwards 1976 for a recently described example and for references to literature on growth faults). Like growth faults this structure occurs within a broadly deltaic environment (the Mersey Coal Measures rest on estuarine deposits immediately and marine deposits at greater depth and were flooded in many places by a transgression of the sea), the delta building out south-eastwards from the Mersey area into a shallow sea. Like growth faults this structure throws down towards the sea, the sedimentary sequence is thicker on the downthrown side and, as with many growth faults, one or other of the blocks is tilted. However, this fault cannot be demonstrated to be a growth fault as corresponding beds on the upthrown and downthrown blocks are not available for measurement and comparison of thickness. The throw, although unknown, $(1.5$ to $35 \mathrm{~m})$ is rather smaller than those quoted for most growth faults. However, it seems likely that the hypotheses offered for the origin of growth faults could also apply in this case e.g. differential compaction (Carver 1968) and regional gravity creep into the deeper parts of a basin (Cloos 1968), especia11y in view of the presence of unstable, hydroplastic carbonaceous silts and likely presence of these at shallow depth beneath the fault. Local instability may have been induced by earth tremors due to movement on deep-seated or distant faults.

Thus for the time being the fault may be recorded but its origin must remain unclear. A tectonic origin is possible but not required by the evidence. A superficial origin of the stress producing the fault is consistent with and more likely than a deep-seated origin on the evidence.

\section{SYNTHESIS}

During the deposition of Microfloral Zone 3b in the Early Permian Epoch the Sassafras area was part of the flood plain of a high sinuosity meandering stream as shown by the nature of the sedimentary rocks and the succession (A1len 1965, pp.165-6). Meander migration led to deposition of several cycles commencing with channel gravels and progressing through thin point-bar sands to swale-fill or ox-bow deposits of carbonaceous siltstone followed in one cycle at least by levée bank and flood plain fine sands and carbonaceous silts.

At some stage during meander migration a normal fault developed with a trend of $33^{\circ}$ and a downthrow to the south-east. The upthrown block was tilted down to the north-west, eroded and on it probably developed a podsolic soil. Later meander migrations caused deposition of levee bank and flood plain sediments over the upthrown block. At several stages in the deposition of the levee bank and flood plain deposits bank collapse led to formation of slurry slumps along axes trending about $128^{\circ}$ and down towards the south-west. Presumably $128^{\circ}$ was approximately the trend of the bank and adjacent channe1.

\section{REFERENCES}

Allen, J.R.L., 1965: A review of the origin and characteristics of Recent alluvial sediments. Sedimentology, 5(2): 89-191.

Banks, M.R., 1962: Permian. In Spry, A.H. and Banks, M.R. (EdS): GEOLOGY OF TASMANIA. J. geol. Soc. Aust., 9(2): 189-215. and Ahmad, N., 1959: Notes of the Cainozoic history of western Tasmania "Malanna Glaciation". Pap. Proc. R. Soc. Tasm., 93: 117-127. and Read, D.E., 1962: The Malbina Siltstone and sandstone. Pap. Proc. R. Soc. Tasm., 96: 19-32. 
Maxwe 11 R. Banks

Carver, R.E., 1968: Differential Compaction as a cause of regional contemporaneous faults. BuZZ. A.A.P.G., $52(3): 414-419$.

Clarke, M.J. and Banks, M.R., 1975: The stratigraphy of the lower (Permo-Carboniferous) parts of the Parmeener Super-group, Tasmania. In Campbell, K.S.W. (Ed.) : GONDWANA GEOLOGY, 453-467. ANU Press Canberra.

Cloos, E., 1968: Experimental analysis of Gulf Coast fracture patterns. BuZZ. A.A.P.G., $52(3): 420-444$.

Conybeare, C.E.B. and Crook, K.A.W., 1968: Manual of Sedimentary Structures. Bur. Miner. Resour. Aust. Bull., 102.

David, T.W.E., 1926: Pleistocene glaciation near strahan, Tasmania. A.N.Z.A.A.S., XVII (1924): 91-103.

Edwards, M.B., 1976: Growth faults in Upper Triassic deltaic sediments, Svalbard. BuZZ. A.A.P.G., $60(3): 341-355$.

Gulline, A.B., Bravo, A.P. and Naqvi, I.H., 1973: Frankford. Geological atlas 1 mile series. Zone 7 sheet 38 Dept. of Mines, Tasmania.

Kemp, E.M., Balme, B.E., Helby, R.J., Kyle, R.A., Playford, P.E., Price, P.L., 1977: Carboniferous and Permian palynostratigraphy in Australia and Antarctica: a review. B.M.R. J. Aust. Geol. Geophys., 2: 177-208.

Stutzer, O. and Noe, A.C., 1940: GEOLOGY OF COAL. Univ. Of Chicago Press: $374-5$.

Truswell, E.M., 1978: Palynology of the Permo-Carboniferous in Tasmania: an interim report. Geol. Surv. Tasm. Bulz., 56.

\section{PLATE EXPLANATIONS}

PLATE 1

Figure 1

A photograph 1ooking north-north-east along the contact. Lower bed with intrastratal folding at lower right.

Figure 2

A photograph of the upthrown block showing the leached zone and the angular conformity.

Figure 3

Lower intrastratally folded bed resting almost directly on conglomerate layer (just below scale which is just over $0.4 \mathrm{~m} \mathrm{long}$ ).

PLATE 2

Figure 1

Lower intrastrally folded bed close to fault. Arrow indicates fold dug to reveal axial trend. View is taken looking east. Scale approximately $0.4 \mathrm{~m} 1$ long.

Figure 2

View taken looking east of lower intrastratally folded bed where it rises into the cutting about $60 \mathrm{~m}$ south of the fault. Scale approx. $0.4 \mathrm{~m}$.

Figure 3

Fine sandstone - carbonaceous siltstone sequence with contemporary minor normal faulting. About $60 \mathrm{~m}$ south of fault; scale approx. $0.4 \mathrm{~m}$.

Figure 4

A view of the fault zone showing the "fault horse" with beds dipping south-east. Scale $1.75 \mathrm{~m}$ long. 
Permian fault in Tasmania
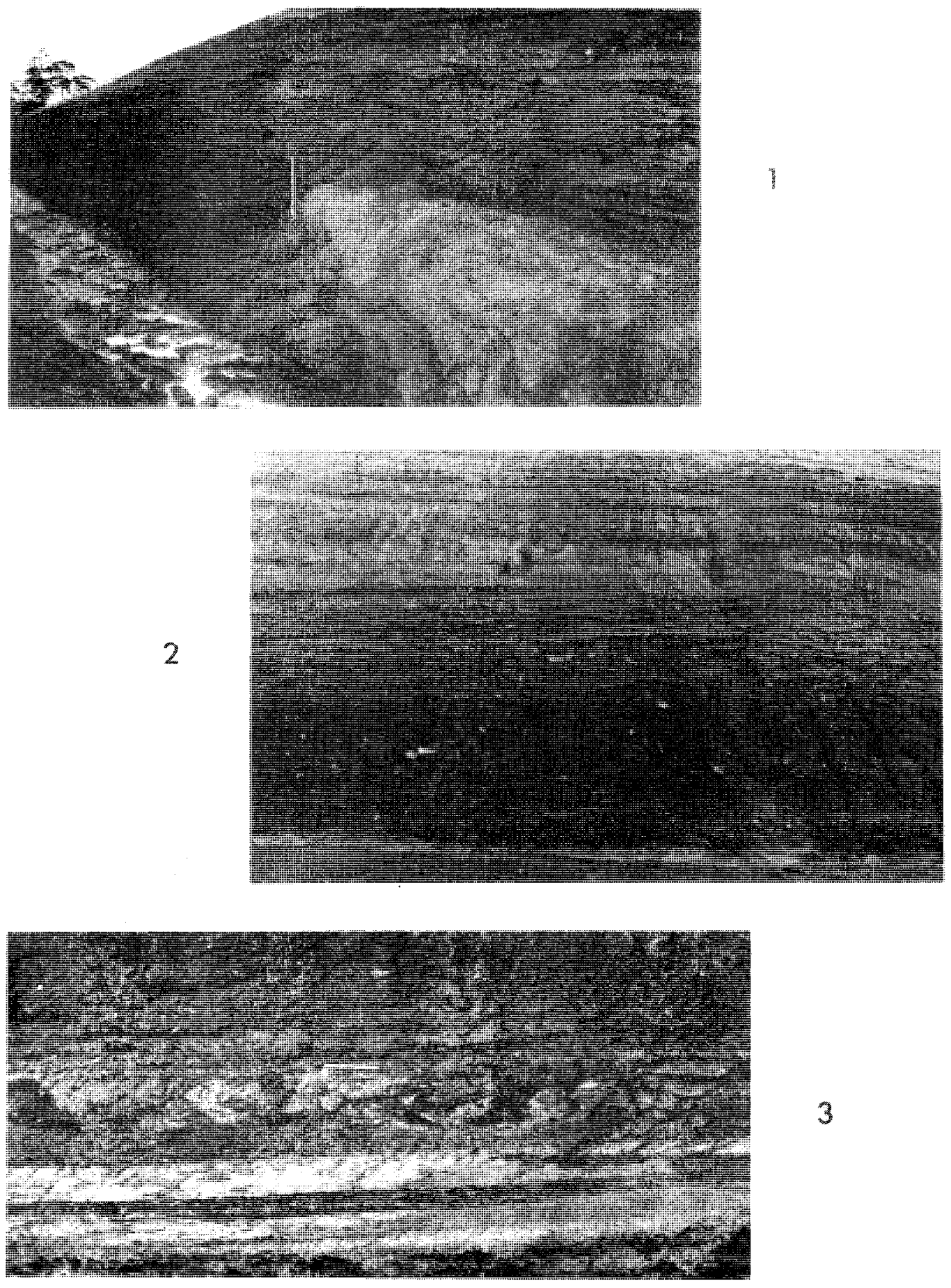

PLATE 1 
Maxwell R. Banks
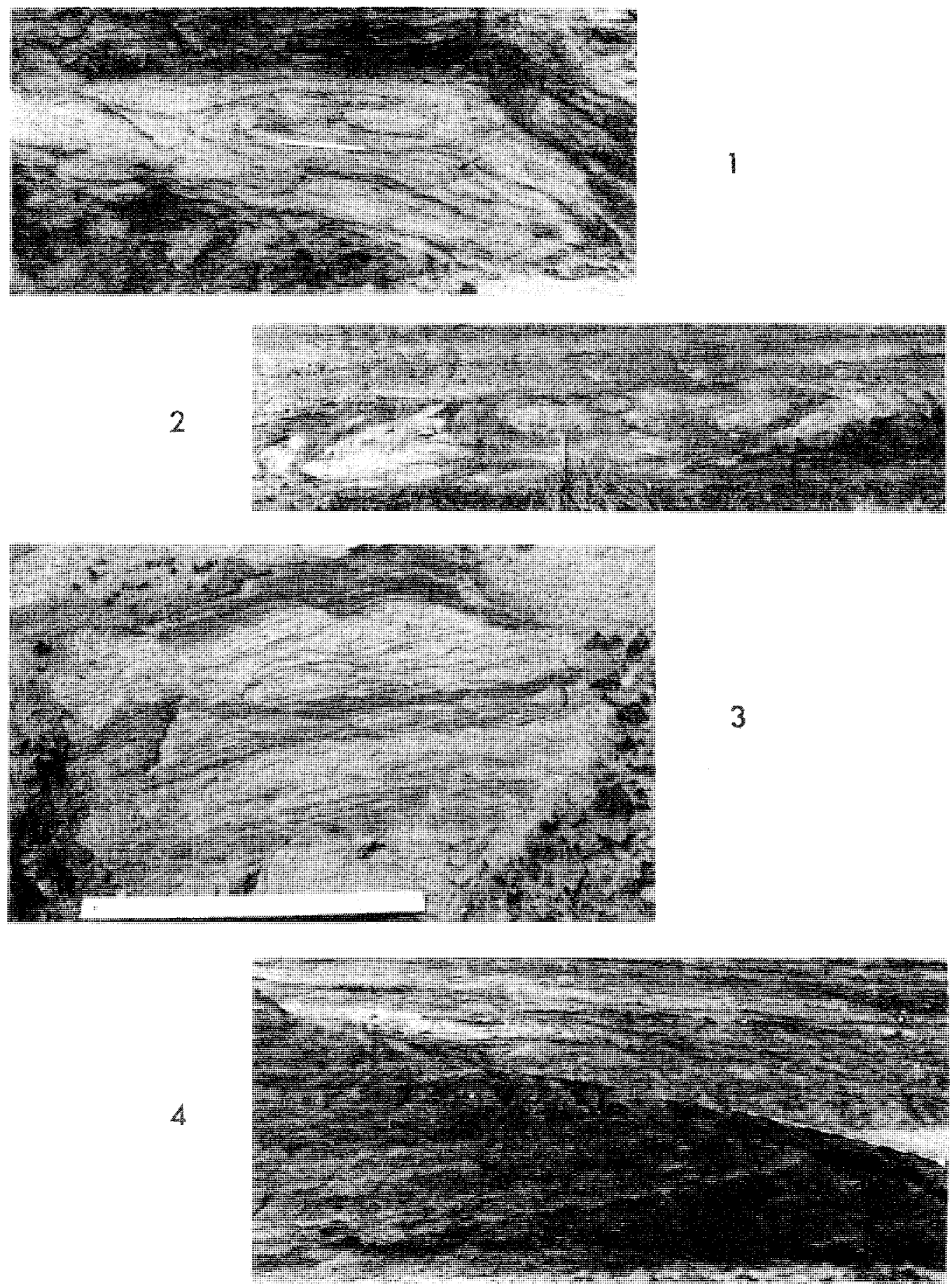

PLATE 2 